\title{
Labor Market Analysis for Developing Countries
}

\author{
Gary S. Fields \\ Cornell University and IZA \\ gsf2@cornell.edu \\ August, 2010
}

\begin{abstract}
This paper is about analyzing labor markets in developing countries, searching for both improved understanding and greater policy relevance. Following a five-part policy evaluation framework, the highlights of labor markets in developing countries are presented. Theoretical models with multiple sectors and segments and empirical analysis using different kinds of data are then reviewed. A brief concluding section addresses some priority research needs.
\end{abstract}

\section{Introduction}

This paper is about analyzing labor markets in developing countries. "Developing countries" include middle-income countries such as Thailand, Brazil, and South Africa as well as low-income countries such as Pakistan, Haiti, and Tanzania. "Developing" is itself something of a euphemism, in that although many of these countries are achieving economic development, many others are not.

The term "labor market" will be used in this paper to refer to the place where labor services are bought and sold. In some labor markets, people are paid employees, selling their labor services to an employer in exchange for a wage or salary. In other labor markets, people are self-employed (also called own-account workers), in which they sell their labor services to themselves. As used here, "labor market" is a comprehensive term including both paid employment and self-employment.

The focus here is on the labor markets for the poor within these countries. Three billion people - almost half of the world's population - are absolutely poor by international standards (living on less than $\$ 2.50$ per person per day in purchasing power parity units), and essentially all of them live in the developing countries (Chen and Ravallion, 2008).

It is often said that the main and often the sole asset of the poor is their labor. So to understand global poverty, one must understand labor markets and labor earnings in the developing world.

Consider policy interventions such as the following: Educating more people in schools. Offering workers a certain type of labor market training. Establishing a workfare program. Regulating layoffs and dismissals. Providing the poor with more to work with, e.g., microcredit. How might such prospective policy interventions be analyzed? 
The following policy evaluation framework has proven useful in a variety of contexts and forms the basis for the analysis that follows:

\section{Policy instruments $\rightarrow$ Model $\rightarrow$ Outcomes $\rightarrow$ Policy evaluation criteria $\rightarrow$ Policy evaluation judgment}

The first step in the framework is to clarify the policy instrument or instruments under consideration: a law that might be passed, a regulation that might be imposed or removed, a tax, a public expenditure, and the like. This is the action that has been undertaken or that is under consideration.

The second part of the framework is to specify the model. Good models endeavor to capture the essential aspects of reality while leaving aside the less essential ones. Models can be theoretical or empirical; the best ones involve an interplay between the two.

Once the policy instrument(s) has/have been specified, the third step is to use the model to predict the likely outcomes. Sometimes these outcomes are theoretical ones, e.g., the policy action in question would increase outcome variable $\mathrm{Y}$ if parameter $\theta$ is greater than a critical value $\theta^{*}$ and decrease it otherwise. Other times, the outcomes are empirical ones, e.g., those countries that have achieved more rapid economic growth are those that have had greater improvements in labor market outcomes.

The policy evaluation is not yet complete. The fourth step is for the evaluator to specify the policy evaluation criteria. (I use the plural, because a full-fledged policy evaluation more often than not relies on multiple policy evaluation criteria rather than a single criterion.) The labor market criteria frequently used by labor economists and policymakers today are increasing employment and reducing unemployment, raising the earnings of those who work so that they and their families can achieve acceptable standards of living, increasing social protection and providing security against the loss of labor market earnings, and insuring that core labor standards in the workplace are honored. Another objective often used in policy evaluation for developing countries is reducing poverty to the maximum extent possible.

Fifth and finally, the outcomes are then evaluated in terms of the evaluation criteria and an overall judgment is made.

Imagine that you are a researcher or a country economist formulating a labor market policy proposal which you propose to take to a client country's government. In a completely-formulated proposal, you would answer the following three questions to the best of your ability:

- What specific labor market objective or objectives are you trying to achieve and by what welfare economic criterion or criteria will you decide if your objective(s) is/are being achieved? 
- What theoretical labor market model are you using to analyze the effects of a proposed policy?

- What is the empirical evidence favoring one view of labor market functioning over another?

These three questions are the ideal, defining what we want to strive for. They are not necessarily what we must have.

Much useful policy-relevant research has a more limited objective. One such limited objective is to get empirical information to help us formulate the right model for a particular country or market context. Are wages set according to supply and demand, by efficiency wage considerations, or by institutions? Do better-educated workers in a country earn more because of human capital created in schools, because of signaling, or because of screening? Why are people working as own-account workers in the informal sector, selling their labor to themselves? Another limited objective is to learn more about a single outcome or parameter. How elastic is the demand for labor in a country? If more jobs are created in one geographic area, how much migration into that area is induced? How important do firms judge various aspects of the investment climate to be? Policy research aimed at these limited objectives is valuable too, and in this paper I present examples of empirical research that has led to interesting policy conclusions.

The balance of this paper proceeds as follows. Labor market analysis for developing countries requires that we look at different issues from the ones typically dealt with by analysts of developed countries. This different labor market context is the subject of Section II. Section III then goes on to talk about the kinds of theoretical models that have been used to analyze developing countries' labor markets and that might be developed further. Section IV addresses the different kinds of empirical work that have been and are being done for developing countries. The paper concludes with some remarks about research priorities.

\section{The Labor Market Context in Developing Countries}

As readers of this journal well know the guiding paradigm for the analysis of labor markets in the developed countries is the wage labor market. We picture the typical employee going to the same office, store, or factory day after day and earning a wage or salary that is payable each week or month.

As we move down the income scale to middle-income countries and then to low-income countries, other types of work arrangements gain in importance. In the developing countries, steady wage employment of the type found in the developed countries is the exception, not the norm.

Workers in poor countries want jobs that are steady and secure, pay well, offer benefits, meet labor standards, and offer social protections - ones that have been called "good 
jobs." The problem they face is that there are not enough good jobs for all who want them and are capable of performing them.

Here are some of the salient features about labor markets in developing countries. For further details, see Fields (forthcoming).

The unemployment rate in developing countries is lower than it is in developed countries. Economists and other labor market analysts use the terms "employment" and "unemployment" in accordance with specific definitions prescribed by the International Labour Organisation (ILO). The unemployment rates in the developed economies and the European Union are above average (8.4\%) while those in East Asia and South Asia are below average (4.4\% and 5.1\% respectively) (ILO, 2010). The fact that unemployment rates are lower in the developing countries is taken by many as a sign that the unemployment rate is a poor measure of labor market distress.

Earnings levels are very low despite long work hours. In most of Asia, Latin America, and Africa, daily wages are no more than one or two U.S. dollars per day. People are working - more often than not, working very long hours. The poor in the developing world are poor despite working long hours.

Not only are incomes low but they are also uncertain. The poor face a "triple whammy": low incomes when they are working, irregular and unpredictable income flows, and a lack of suitable financial tools (Collins, Morduch, Rutherford, and Ruthven, 2009). They respond by managing their money carefully.

Women are disadvantaged in developing country labor markets. Women's earnings are lower, women's work is more likely to be informal, and women are disproportionately in casual positions.

The composition of employment is very different in developing countries from what it is in developed countries. As compared with the developed countries, the developing countries have a smaller percentage of people working in offices and factories and a larger percentage working in agriculture. In the developing countries, self-employment, ownaccount work, and unpaid family work are more important, and paid employment is less important.

The great majority of those working in developing countries work in the private sector, not the public sector. A large majority of those who work in the private sector are not registered with the government and therefore do not receive job-related social protections. Nine out of ten workers in the developing world are in the private sector. In a typical low-income country, some $90 \%$ of these workers are excluded from governmentrun economic security programs.

Typically, the better jobs are in wage employment, not self-employment. But within wage employment, the regular wage jobs are better than casual wage jobs. For these reasons, "everybody" in developing countries wants a regular wage job. 
The problem the poor face is that not enough regular wage employment is available for all who would like wage jobs and are capable of performing them. Would-be wage employees could respond to the lack of wage jobs by remaining unemployed and continuing to search. However, few do, for the simple reason that they cannot afford to. They find it better to create their own self-employment opportunities. Banerjee and Duflo (2007, p. 162) write: "Nothing seems more middle class than the fact of having a steady well-paying job. While there are many petty entrepreneurs among the middle class, most of them do not seem to be capitalists in waiting. They run businesses, but for the most part only because they are still relatively poor and every little bit helps. If they could only find the right salaried job, they might be quite content to shut their business down."

Developing country labor markets are usually thought to be segmented. While definitions differ, the one I prefer has two defining features: first, for workers of any given skill level, some jobs are decidedly better than others; and second, access to the better jobs is rationed in the sense that not all who want those jobs and who are capable of performing them are able to get them. Segmented labor market models will be analyzed in depth in Section III.

Not all microenterprise operators and family workers are doing such work involuntarily. Some could be working as wage employees but choose not to for reasons such as wanting to be their own bosses, trying to make it big on their own, and (especially for women) simultaneously working and fulfilling child-care responsibilities. Surely, some of the selfemployed are doing so by choice, but how a large a percentage they are remains unsettled in the literature.

Apart from low earnings levels and lack of social protections, a large number of jobs are downright miserable. It is this fact that has led the ILO to organize its efforts around the theme of Decent Work and to try to close the Decent Work Deficit.

What the developing countries have is an employment problem - that is, poverty among those who work - rather than an unemployment problem. While more than 200 million people were unemployed in 2009, some 1,300 million people (i.e., 1.3 billion) belonged to the working poor, defined as workers who lived in families below the internationallyused two dollar a day poverty line. In other words, $85 \%$ of the world's poor are working.

\section{Theoretical Models with Multiple Segments or Sectors}

This section presents models in which the aggregate labor market consists of a small number of labor market segments or sectors linked to one another by actual or potential mobility of workers and/or firms (Dixit, 1973; Basu, 1997; Fields, 2007). The reason we need different segments or sectors is that some parts of the labor market operate in a qualitatively different manner from others. The reason we need models that put together these various segments is that conditions in one segment affect and are affected by conditions in other segments. 
When Occam's Razor is employed and the number of segments is limited to just two, the models are called dualistic. Here, the two segments will be called formal and informal, though they might also have been called industry and agriculture, urban and rural, modern and traditional, capitalist and subsistence, wage employment and selfemployment, covered and non-covered, high-income and low-income, and good jobs and bad jobs.

The pathbreaking work on multisector labor market models in the context of economic development was done by two Nobel Prize-winning economists, W. Arthur Lewis (1954) and Simon Kuznets (1955). Lewis and Kuznets agreed that economic growth is marked by the gradual shift of workers out of the lower-paying segments and into the higherpaying ones. They also agreed that the main development problem is not unemployment but rather low incomes in the poorer parts of the economy. And they agreed to that the same worker would earn quite different amounts depending on where he or she is located.

The emergence of human capital theory in the 1960s by Schultz (1961) and Becker (1964) also earned its developers the Nobel Prize. According to their version of the human capital model, education and training would improve workers' skills, enabling them to work in different economic sectors and earn more. Other Nobel Prize winners modeled the returns to education differently. Signaling models maintain that workers get educated in order to signal to employers that they (the educated workers) are inherently more productive than other workers (Spence, 1973). Screening models examine what happens when the educational system certifies which workers are more productive than others and the educated workers use their education to move to the front of the queue and be hired preferentially for jobs for which education is advantageous but not required (Stiglitz, 1975). And rat-race models contend that individual i or firm $\mathrm{j}$ may be able to get ahead by doing more of something, but if that very action causes individual $m$ or firm $n$ to fall behind, the social benefits may be very much smaller than the private benefits (Akerlof, 1976).

Another early development was the dual labor market model of Doeringer and Piore (1971). Wachter (1974, p. 639) summarized the dual labor market model thus:

First, it is useful to dichotomize the economy into a primary and a secondary sector. Second, the wage and employment mechanisms in the secondary sector are distinct from those in the primary sector. Third, economic mobility between these two sectors is sharply limited, and hence workers in the secondary sector are essentially trapped there. Finally, the secondary sector is marked by pervasive underemployment because workers who could be trained for skilled jobs at no more than the usual cost are confined to unskilled jobs.

Wachter and also Cain (1976) stressed that for labor market dualism to exist, different wages must be paid in different sector to comparable workers. Empirical researchers then showed that observationally equivalent workers earned different amounts in different parts of an economy; see Fields (1980) for an early review. However, skeptics such as Rosenzweig (1988) remained unconvinced, maintaining that different earnings reflected 
differences in unmeasured human capital. The alternative to a segmented labor market model is a unitary labor market model, in which all workers with given skills receive the same wage regardless of which part of the labor market they work in. Given the differences in labor market outcomes presented in Section II, the unitary view does not seem right, and so I continue to find it more fruitful to think about models with two or a multiplicity of segments.

Where a large part of the literature has gone in the intervening years is to continue to develop the segmented labor market approach. The three main components have been to model the formal sector labor market, model the informal sector labor market, and model the links between the two.

On modeling the formal sector labor market, options are the supply-demand model with full market-clearing (as in the standard labor market textbooks), supply and demand models with institutional wage determination (as in the textbook model of a labor market with a minimum wage), non-market-clearing because of resistance on the supply side of the labor market (Bardhan and Rudra, 1981; Solow, 1990), non-market-clearing for efficiency wage reasons (Katz, 1986; Weiss, 1990), and a range of other models including matching models (Mortensen and Pissarides, 1999), job creation and destruction models (Davis, Haltiwanger, and Schuh, 1996), ranking models (Blanchard and Diamond, 1994); and imperfect information models (Stiglitz, 2002).

On modeling the informal sector labor market, most of the models build on the Lewis and Kuznets view that people are working informally because they are unable to work formally. My own early work (Fields, 1975) falls into this category, as does Harberger (1971). But it was later recognized that there is a fundamental duality within the informal sector, whereby some people work in a lower tier because they can do no better, while others work in an upper tier into which entry is restricted because of human capital and financial capital requirements (Fields, 1990). Some analysts maintain that in Mexico and other Latin American countries, self-employment in the informal sector may be more attractive for a majority of workers compared to work as wage employees in the formal sector (Maloney, 2003, 2004; World Bank, 2007). Opinion remains divided on how many people are working in each tier.

Analysts have also modeled intersectoral linkages in a variety of ways. One is a noncompeting groups model in which individuals belong to one labor market segment or another, and they cannot or will not switch from one to another (as in many human capital models). A second is an integrated labor market model which starts with two or more sectors but assumes that all of the equilibrating forces that apply to a single labor market with market-clearing also apply to a labor market with a multiplicity of sectors, so that wages equalize across sectors; nearly all international trade models have such a labor market specification (Krugman and Obstfeld, 2003). A third way of modeling intersectoral linkages is the crowding model, which assumes that any worker who is not employed in the high wage part of the economy takes up employment in the low wage part of the economy; the Lewis and Kuznets models mentioned above can be recognized as crowding models. A fourth specification is that one sector maintains higher wages than 
another, but the two sectors are linked via workers' job search behavior, such that in equilibrium the expected wages associated with the two sectors are equal to one another (Harris and Todaro, 1970). Finally, a fifth type of model posits that workers choose occupations which maximize their current and future returns, but because of imperfect capital markets, occupations that require high levels of investment cannot be entered by persons with low initial wealth. The distributions of workers in different occupations evolve over time as individuals invest their time and money to increase their wealth or the wealth of their children (Banerjee and Newman, 1993).

Where the field is at present is that we have many multisector models incorporating a variety of features of developing country labor markets. The Harris-Todaro model was formulated as a stylization of the Kenyan economy. But for researchers seeking stylizations of India, South Africa, Brazil, or other developing economies, it remains for appropriate labor market models to be developed to fit each country's particular set of conditions. For further details, see Fields (2007).

\section{Empirical Research on Labor Markets and Labor Market Policies}

In this section, I discuss five kinds of data that have been used to analyze developing countries' labor markets - micro cross-sectional data, panel data, aggregate crosssectional data, time series data, and experimental data - and present examples of empirical studies that have used each.

\section{A. Micro cross-sectional data}

Micro data sets exist for most developing countries. A typical issue of any of the leading development economics journals contains a number of papers using such data sets.

Studies analyzing micro data enable researchers to find out what makes a difference at the level of the individual worker or the individual household. This type of data analysis is at the core of most contemporary research studies on labor markets, and the literature using such data is correspondingly huge.

The question these studies typically answer is, which individuals or which firms have higher levels of the dependent variable Y? More specifically, the regression coefficients can be understood thus: when we compare those individuals or firms for which an independent variable $\mathrm{X}$ is one unit higher, on average how much higher is $\mathrm{Y}$ ?

It is well-known that the answers given by simple tabulations and ordinary least squares regressions can be problematical even within their own frame of reference. The two main problems are correlation but not causation and the problem of bias in the estimated coefficients. In day-to-day labor economics, a single solution is commonly offered to both problems, namely, instrumental variables estimation. Deaton $(1997,2000)$ has presented the advantages of instrumental variables methods as well as their limitations; see also Bound, Jaeger, and Baker (1995) and Staiger and Stock (1997). As Bound, Jaeger, and Baker put it so graphically in the title of the working paper version of their 
paper, "the cure can be worse than the disease." That observation does not, however, stop labor economists from instrumenting at virtually every opportunity.

Another way of dealing with problems in micro data analysis is to adopt a regression discontinuity design. Many such studies are appearing using this method as well. See Imbens and Lemieux (2007) for a review.

But less attention is paid to another problem: that the micro level results typically make certain assumptions about market structure that may not hold in the circumstances analyzed. For example, when more people are educated, how do we know that the newlyeducated will be employed at all, let alone in jobs where they will gain as much in earnings as the differential that we now observe between more-educated and lesseducated workers? Because of this problem, when the results of such regressions are used to draw "policy implications" - for example, about educating more people - they may not be implications at all.

Notwithstanding the possible misuses of micro data regressions, it would be foolhardy in the extreme to dismiss them. Such regression results are very useful information to have. My point is that we need to be suitably modest in drawing policy inferences from them.

\section{B. Panel data.}

Panel data analysis is a relatively new and promising approach in developing countries Panel studies follow the same individuals or families over time. Such studies enable development processes to be analyzed in ways that analyses of comparable cross-sections cannot. Two areas in which a great deal of policy-relevant knowledge has been gained are the effects of policy interventions on treated individuals and the determinants of income and earnings mobility.

On the first topic, studies of policy interventions estimate such measures as the average treatment effect, the average treatment effect for those treated, and the distribution of treatment effects for different individuals. Heckman (2001) and Ravallion (2008) are among those who present comprehensive overviews of the relevant issues in estimating such magnitudes.

Empirical research of this type has proved informative in the context of developing countries. One example is the study by Kugler (2005) of a policy change in Colombia, which replaced its earlier system of severance payments with a new system of mandated severance payments savings accounts (SPSAs). Kugler's question was whether part of this obligation was shifted to workers in the form of lower wages. Using a difference-indifference-in-difference estimator, she concluded that $60-80 \%$ of the total SPSA contributions were shifted to workers in the form of lower wages, thus disproving the view held by some that such mandates would be "free" to the workers.

Another example of using panel data to estimate the effects of a labor market policy change is the study by Ravallion et al. (2005) of Argentina's workfare program, known in 
Spanish as Trabajar (To Work). Using a difference-in-difference-in-difference estimator, the authors concluded that workers suffered large earnings losses from retrenchment and experienced sizeable income gains from participating in Trabajar, while those who left the program lost considerable amounts relative to those who stayed.

Another topic that has been explored fruitfully using panel data in developing countries is income and earnings mobility. "Income" denotes income from all sources, while "earnings" denotes income from wage employment, salaried employment, and selfemployment only.) One question that has been asked is, how have economic growth and economic decline affected income or earnings changes for different groups in the population: men vs. women, better-educated vs. less-educated, initially high earners vs initially lower earners, and so on? Fields et al. (2007) studied this question for Argentina, Mexico, and Venezuela. They found that notwithstanding the high and generally rising earnings inequality in all three countries, both in times of economic growth and in times of economic decline, the largest average earnings gains in currency units (pesos in the case of Argentina and Mexico, bolivares in the case of Venezuela) were experienced by those who were initially at the bottom end of the earnings distribution, and they also found that a key variable explaining earnings change was the change in employment status between formally employed, informally employed, and unemployed.

In addition to the work done on earnings mobility, there also is a literature on income and consumption mobility in developing countries. See the work of the Chronic Poverty Research Centre (www. chronicpoverty.org) on countries around the world.

C. Aggregate cross-sectional data.

The analysis of aggregate data is a useful and often-neglected starting point for policy analysis, permitting answers to questions such as the following. Do workers participate proportionally in economic growth? More generally, how do labor market conditions change during times of growth and decline? How do the outcomes in one country compare with those in another? How do changes in labor market outcomes for one population sub-group compare with those of another? Is economic growth jobless, and if so, under what circumstances?

The general result that has come out of such aggregate data analysis for a limited number of countries is that economic growth has generally led to improved conditions in labor markets as gauged by indicators such as the rate of unemployment, composition of employment, real earnings levels, earnings inequality, and poverty. Conversely, when such labor market aggregates have not improved, typically it is because economic growth has not taken place.

This line of research suggests that to improve labor market conditions for workers in general and for the poor in particular, economic growth should be sought. The pessimistic view - that workers have been left out or even made poorer when economic growth has taken place - is not supported by the data as a generalization. 
D. Time series data.

The simplest kind of time series data is that which follows given variables within a country over time. Time series data allow for the determinants of changes over time to be modeled explicitly. For example, the wage elasticity of formal sector labor demand in South Africa was estimated using such data; Fields, Leibbrandt, and Wakeford (2000) present their own and earlier estimates. Despite differences in time periods and estimation methods, these studies concurred that the range of estimates was on the order of -0.4 to -0.6 - certainly not zero. This finding led policy-makers in that country to recognize that the push by the Congress of South African Trade Unions for higher wages would likely result in reduced formal sector employment.

A more comprehensive kind of data combined time series with cross sections - that is, time series are presented for a number of countries or for groups or regions within countries. Such is the case for a study of the effects of labor market regulations in India. Besley and Burgess (2004) used time series data for each of India's states to assess the effects of amending India's Industrial Disputes Act in an allegedly pro-worker direction. Using sophisticated econometric methods, they estimated that the legislation had led to an informalization of the economy and to higher urban poverty than would have been the case without the amendments. Like Besley and Burgess, Ahsan and Pagés (2009) also used cross-section time-series methods. Their main result was that de jure legal amendments and de facto use of contract labor hurt formal sector workers and imposed substantial costs on society.

\section{E. Experimental data.}

A burgeoning literature in development economics uses randomized field experiments to find out what works in practice. Here are three examples of the kinds of lessons to come from this kind of literature.

First, to address the problem of teacher absenteeism in India, teachers in randomlyselected schools were given a camera with a tamper-proof date and time function and told to take a picture of him/herself and the students at the beginning and end of each school day. Teachers were offered a bonus based on the number of days they actually came to school. The evaluation results (Duflo and Hanna, 2005) showed that the absence rate in the treatment schools $(22 \%)$ was half of that in the control schools $(42 \%)$.

A second example of randomized treatment in the labor market is the Colombian workfare program Empleo en Acción (Employment in Action). In an evaluation of this program, Attanasio, Meghir and Vera-Hernandez (2007) found that the program positively influenced the number of hours worked and both individual and household labor income. Household income increased more than individual's income, indicating that the program had some positive externality on the other members of the household.

A third application of experimental methods is in the evaluation of job training in Latin America. In one study, Card et al. (2007) studied the Dominican Republic and found that 
job training had no significant impact on the likelihood of having a job, but it did have a marginally significantly impact for wages and also for having health insurance coverage conditional on being employed. Another randomized evaluation of a training program is reported by Attanasio, Kugler and Meghir (2007) for Colombia. Contrary to Card et al's findings for the Dominican Republic, this study found that in Colombia job training had large, widespread effects on women, but fewer and less pronounced effects on men.

Literally hundreds of experimental studies have been completed, and a great many others are under way. Overviews of this literature are presented in Duflo (2006), Banerjee (2007), and www.povertyactionlab.org.

\section{Concluding Remarks}

In this concluding section, I briefly highlight four priority areas for future research relating to the issues raised in this paper.

The first is to understand better how people in developing countries are working and why they are doing what they are doing. While more descriptive analysis would be informative, even more valuable for our understanding would be knowledge about what is enabling some workers to obtain better labor market outcomes and what is constraining others from making such gains.

The second is the need for empirically-grounded theoretical labor market models that can be used in the formulation of policy. There is some value in developing single-sector models and representative agent models, but it would be more helpful to have multisector models in which labor markets are segmented, incorporating the key features of labor markets in the country being analyzed.

The third is the need for sector-level and market-level analysis of various outcomes. Analyses at these levels are likely to be more illuminating than would additional microlevel regressions.

And fourth is the need for in-depth empirical analysis on which particular policy interventions matter or do not matter. We can gain such knowledge from statistical and econometric studies, from experimental studies, or from a mix of the two. What we need most are additional studies that tell us specifically what has made a positive difference and what has not - for example, that student performance and hence workers' skills can be raised by improving teacher quality but not by reducing class sizes. Not as important are more studies that say that those individuals/households/workers/students with more of characteristic $X$ have such-and-such higher value of outcome variable $Y$ in country $Z$.

Much remains to be learned about these and other issues such as child labor, entrepreneurship, employment and workplace protection, and many other others. This paper will have succeeded if it has suggested new ways of thinking to those readers who already work on developing countries' labor markets and stimulated others to want to work in this area. 


\section{References}

Ahsan, Ahmad and Carmen Pagés (2009). "Are All Labor Regulations Equal? Evidence from Indian Manufacturing," Journal of Comparative Economics 37: 62-75.

Akerlof, George (1976). "The Economics of Caste and of the Rat Race and Other Woeful Tales," Quarterly Journal of Economics 90: 599-617.

Attanasio, Orazio, Adriana Kugler, and Costas Meghir (2007). "Effects of Youth Training in Developing Countries: Evidence from a Randomized Training Program in Colombia." University College London. Processed.

Attanasio, Orazio, Costas Meghir, and Marcos Vera-Hernández (2007). "Investigating Different Benefits of Workfare Programs." University Collage London. Processed.

Banerjee, Abhijit (2007). Making Aid Work. (Cambridge: Boston Review and MIT Press).

Banerjee, Abhijit and Esther Duflo (2007) "The Economic Lives of the Poor", Journal of Economic Perspectives, 21(1): 141-167.

Banerjee, Abhijit V. and Andrew F. Newman (1993). "Occupational Choice and the Process of Development," Journal of Political Economy 101 (2): 274-298.

Bardhan, P.K. and A. Rudra (1981). "Terms and Conditions of Labour Contracts in Agriculture: Results of a Survey in West Bengal 1979," Oxford Bulletin of Economics and Statistics 89-111.

Basu, Kaushik (1997). Analytical Development Economics. (Cambridge, MA: MIT Press).

Becker, Gary S. (1964). Human Capital. (New York: Columbia University Press for the National Bureau of Economic Research).

Besley, Timothy and Robin Burgess (2004). "Can Labor Regulation Hinder Economic Performance? Evidence from India," Quarterly Journal of Economics 119(1): 91-134.

Blanchard, Olivier and Peter Diamond (1994). "Ranking, Unemployment Duration, and Wages." Review of Economic Studies 61: 417-434.

Bound, John, David A. Jaeger, and Regina M. Baker (1995). "Problems with Instrumental Variables Estimation when the Correlation Between the Instruments and the Endogenous Explanatory Variable is Weak," Journal of the American Statistical Association 90: 443-450. 
Cain, Glen (1976). "The Challenge of Segmented Labor Market Theories to Orthodox Theories," Journal of Economic Literature 14:4, 1215-1257.

Card, David, Pablo Ibarraran, Ferdinando Regalia, David Rosas, and Yuri Soares (2007). "The Labor Market Impacts of Youth Training in the Dominican Republic: Evidence from a Randomized Evaluation," National Bureau of Economic Research Working Paper 12883.

Chen, Shaohua and Martin Ravallion.(2008), "The Developing World Is Poorer Than We Thought, but No Less Successful in the Fight Against Poverty," World Bank Policy Research Working Paper 4703, August.

Collins, Daryl, Jonathan Morduch, Stuart Rutherford, and Orlanda Ruthven (2009). Portfolios of the Poor. (Princeton: Princeton University Press).

Davis, Steven J., John Haltiwanger, and Scott Schuh (1996). Job Creation and Destruction. (Cambridge, MA: MIT Press).

Deaton, Angus (1997). The Analysis of Household Surveys. (Baltimore: Johns Hopkins University Press).

Deaton, Angus (2010). "Instruments, Randomization and Learning about Development," Journal of Economic Literature, XLVIII (2), 424-455.

Dixit, Avinash K. (1973). "Models of Dual Economies," in James Mirrlees and Nicholas Stern, eds., Models of Economic Growth: Proceedings of a Conference Held by the International Economic Association at Jerusalem. (New York: International Economic Association).

Doeringer, Peter B. and Michael J. Piore (1971). Internal Labor Markets and Manpower Analysis. (Lexington, MA: Heath).

Duflo, Esther (2006). "Field Experiments in Development Economics," in Richard Blundell, Whitney Newey, and Torsten Persson, eds., Advances in Economic Theory and Econometrics. Cambridge University Press.

Duflo, Esther and Rema Hanna (2005). "Monitoring Works: Getting Teachers to Come to School," NBER Working Paper No. 11880.

Fields, Gary S. (1975). "Rural-Urban Migration, Urban Unemployment and Underemployment, and Job Search Activity in LDC's," Journal of Development Economics 2: 165-188. 
Fields, Gary S. (1980). "Education and Income Distribution in Developing Countries: A Review of the Literature," in Timothy King, ed., Education and Income (Washington: World Bank).

Fields, Gary S. (1990). "Labour Market Modeling and the Urban Informal Sector: Theory and Evidence," in David Turnham, Bernard Salomé, and Antoine Schwarz, eds., The Informal Sector Revisited. (Paris: Development Centre of the Organisation for Economic Co-Operation and Development).

Fields, Gary S., "Employment in Low-Income Countries: Beyond Labor Market Segmentation?" (2007). In Pierella Paci and Pieter Serneels, eds., Employment and Shared Growth. (Washington: World Bank).

Fields, Gary S. (forthcoming). Earning Their Way Out of Poverty.

Fields, Gary S., Robert Duval Hernández, Samuel Freije, and María Laura Sánchez Puerta (2007). "Earnings Mobility in Argentina, Mexico, and Venezuela: Testing the Divergence of Earnings and the Symmetry of Mobility Hypotheses." Cornell University. Processed.

Fields, Gary S., Murray Leibbrandt, and Jeremy Wakeford (2000). Key Labour Market Elasticities. Report submitted to the South African Department of Finance.

Harberger, Arnold C. (1971). "On Measuring the Social Opportunity Cost of Labor," International Labour Review 103: 559-579.

Harris, John and Michael Todaro (1970). "Migration, Unemployment, and Development: A Two Sector Analysis," American Economic Review, 40: 126-142.

Heckman, James J. (2001). "Micro Data, Heterogeneity, and the Evaluation of Public Policy: Nobel Lecture," Journal of Political Economy 109(4): 673-748.

ILO (annual). Global Employment Trends. (Geneva: ILO).

Imbens, Guido and Thomas Lemieux (2007) "Regression Discontinuity Designs: A Guide to Practice," Journal of Econometrics.

Katz, Lawrence (1986) "Efficiency Wage Theories: A Partial Evaluation," NBER Macroeconomics Annual.

Krugman, Paul R. and Maurice Obstfeld. (2003). International Economics, Sixth Edition. (Boston: Addison Wesley).

Kugler, Adriana D. (2005). "Wage-Shifting Effects of Severance Payments Savings Accounts in Colombia," Journal of Public Economics 89: 487-500. 
Kuznets, Simon (1955). "Economic Growth and Income Inequality," American Economic Review 45: 1-28.

Lewis, W. Arthur (1954). "Economic Development with Unlimited Supplies of Labour," Manchester School, 22: 139-191.

Maloney, William F. (2003). "Informal Self-Employment: Poverty Trap or Decent Alternative," in Gary S. Fields and Guy Pfeffermann, eds., Pathways Out of Poverty. (Boston: Kluwer).

Maloney, William F. (2004). "Informality Revisited," World Development. 32(7): 11591178.

Mortensen, Dale and Christopher Pissarides (1999). "Job Reallocation, Employment Fluctuations, and Unemployment," in Michael Woodford and John Taylor, eds, Handbook of Macroeconomics, Volume 1B. (Amsterdam: Elesiver Science/NorthHolland) 1171-1228.

Ravallion, Martin (2008). "Evaluating Anti-Poverty Programs," in T. Paul Schultz and John Strauss, eds., Handbook of Development Economics, Volume 4. (Amsterdam: North-Holland).

Ravallion, Martin, Emanuela Galasso, Teodoro Lazo, and Ernesto Philipp (2005). "What Can Ex-Participants Reveal About a Program's Impact?", Journal of Human Resources. XL(1): 208-230.

Rosenzweig, Mark (1988). "Labor Markets in Low Income Countries," in Hollis Chenery and T.N. Srinivasan, eds., Handbook of Development Economics, Volume 1.

(Amsterdam: North Holland).

Schultz, T.W. (1961). "Investment in Human Capital," American Economic Review. LI: $1-17$.

Solow, Robert (1990). The Labour Market as a Social Institution. (Oxford: Blackwell).

Spence, Michael (1973). "Job Market Signaling," Quarterly Journal of Economics. 87(3): 355-374.

Staiger, Douglas and James Stock (1997)."Instrumental Variables Estimation with Weak Instruments," Econometrica.

Stiglitz, Joseph E. (1975). "The Theory of 'Screening,' Education, and the Distribution of Income," American Economic Review 65(3): 283-300.

Stiglitz, Joseph E. (2002). "Information and the Change in the Paradigm in Economics," American Economic Review 92(3): 460-501. 
Wachter, Michael (1974). "Primary and Secondary Labor Markets: A Critique of the Dual Approach.”Brookings Papers on Economic Activity 1974 3: 637-680.

Weiss, Andrew (1990). Efficiency Wages: Models of Unemployment, Layoffs, and Wage Dispersion. (Princeton, NJ: Princeton University Press).

World Bank (2007). Informality: Exit and Exclusion. (Washington: World Bank). 